\title{
Pragmatic Metaphorisation of Nature Silence Effect in Poetic Discourse
}

\author{
Vladyslava Kulish ${ }^{1}$, Maryna Chernyk ${ }^{1}$, Olena Ovsianko ${ }^{1}$, Olha Zhulavska ${ }^{1}$ \\ ${ }^{1}$ Department of Germanic Philology, Sumy State University, Sumy, Ukraine \\ Correspondence: Vladyslava Kulish, Department of Germanic Philology, Sumy State University, 40007, 2 \\ Rymskogo-Korsakova Str., Sumy, Ukraine. E-mail: v.kulish@nuos.pro
}

Received: December 13, 2021

Accepted: January 26, 2022

Online Published: February 4, 2022

doi:10.11114/smc.v10i1.5479

URL: https://doi.org/10.11114/smc.v10i1.5479

\begin{abstract}
The article considers the pragmatics of silence image in English poetry. Silence being a communicative unit is associated with verbal and non-verbal communication. The purpose of the article is to study the discursive and communicative-pragmatic nature of poetical images of silence in the English-language literary discourse. The universal and cultural functions of this notion were analysed and the main approaches to the poetical silence study were determined. It became clear that the phenomenon of Nature Silence can be actualised with the help of Nature and other landscape images in the field of English literary discourse. Such images must belong to the paradigm of English landscape images represented by Earthy, Aerial and Celestial substantial nature symbols. In terms of discourse-communicative approach to the study of communicative silence, these elements play an important role of the main producers of Nature Silence. This work proposes the new pragmatic and communicative approach of understanding the Nature silence in English literary discourse. The main verbal units that can actualise the poetical image of silence are characterised by the permanent correlation with the different symbols of nature, showing the dominant and peripheral characteristics. Being the pragmatic realisation of silence image, motives of Nature Silence may be considered both as dominant and background.
\end{abstract}

Keywords: Silence image, poetical image, pragmatic realization, Nature Silence, motives of Nature Silence

\section{Introduction}

Communication is an essential part and precondition of life and social activity. Pragmatics in a broad sense and according to Rudolf Carnap (1939) "is a field which takes into consideration the action, state and environment of a man who speaks and hears". Therefore, we along with Adrian Akmajian (2001) take the term pragmatics to cover the study of language use, and particular the study of linguistic communication, in relation to language structure and context of utterance. In linguistic studies, the notion of communication is closely related to speaking, but it should be noted that these notions have different meanings. According to Florii Batsevych (2010), speaking is a general notion that means the set of connections and interconnections between people, society, experience, skills, and results of different activities. The notion of communication is more specific - it is connected with only one type of speaking and implies the semantically meaningful aspect of social interconnection in the process of sharing information in different speaking activities. One of the elements of communicative linguistics is poetical communication, which is represented by constructive units of the poetical text in different poetical communication acts (Aimukhambet et al., 2017).

The communicative approach to the study of the poetical texts is based on the analysis of the communicative conditions, which are the main content component of the text (Romaniuk, 2018). The comprehension of the speaking situation cannot exist without the understanding of the main categories of pragmalinguistics - namely, participants of communication, conditions of communication (presupposition, chronotope, communicative environment), organisation of communication (motives, aims, and strategies), and way of communication (channel, regime, style, genre of communication) (Skliarenko et al., 2019). According to verbal communication theory, communication is a human speech activity. The Message Model is the most common and popular conception of human linguistic communication. According to it, communication is presented by the speaker and hearer. The speaker acts as a transmitter and the hearer acts as a receiver and the vocal-auditory path (the sound wave) is the relevant channel (Romaniuk, 2019). This activity is connected with transition from the object description to the subject image or ideal (Batsevych, 2010). This model accounts for certain features: it predicts that communication is successful when the hearer decodes the same message that the speaker encodes. Thus, the Message Model of communication must assume that the communicative intention is 
determined by the meaning of the sentence, and the speakers speak literally and directly (Akmajian, 2001).

Psychological analysis of each activity foresees its structuring into the following elements: 1) motive - a reason, or stimulus to act; 2) aim - conscious understanding of the result, which can be gained in the process of the activity (the aim is closely connected with the motive and influences the further activity); 3) action - a realisation of something according to specific aim connected with a general aim; 4) operation - a way of action realisation (Batsevych, 2010; Kulakhmetova et al., 2017). Basically, the connection of these elements can be presented as inferenxial in the Inferential Model. This model of linguistic communication works when the hearer, upon hearing an expression, recognizes the speaker's communication intention. It means that linguistic communication works when speaker and hearer use the system of inferential strategies (direct/indirect, literal/nonliteral) (Akmajian, 2001). Speech activity has the same features as any other activity and, according to features classification, it relates to inner, literary, and cognitive characteristics. The theory of speech activity includes psycholinguistics (studying inner psychophysiological conditions of speech production and understanding) and communicative linguistics (a theory of speech communication investigating psychosocial conditions of speech production and understanding). Such tandem speech communication is considered as social interconnection, including information sharing and description of social connections during speech communication (Issakova et al., 2021).

In frames of communicators' interaction, silence in the English-language literary discourse is characterised by dialogical nature. In literary discourse and speech, there are both non-verbal and verbal components of communication. Non-verbal components - including silence - are elements of the communicative code with non-verbal (but symbolic) nature, serving to create, transmit, and perceive messages with the help of speech code (Batsevych, 2010). Verbal components are the means of language code - i.e., words, phrases, sentences (messages), and texts - which transmit information (Batsevych, 2010; Tsvetkova et al., 2021). The main question is, how exactly is the non-verbal component of communication, such as silence, transmitted in written speech? The answer becomes transparent when researching both lexicographic and empirical sources of information. Poetical silence in the English-language literary discourse is realised at various structural levels, namely lexical (due to dominant verbalisers and peripheral synonyms), syntactic (due to impersonal sentences), and graphic (due to punctuation marks that indicate a break in the written speech).

Thus, the purpose of our research is to study the discursive, communicative, and pragmatic nature of poetical images of silence in the English-language literary discourse. The purpose of the study led to the following tasks:

- to systematise scientific approaches to the study of literary image in terms of contemporary linguistics;

- to develop a comprehensive methodology for analyzing the poetical image of silence in the English-language literary discourse;

- to identify the main verbalisers of silence as a non-verbal means of communication in the English-language literary discourse;

- to model the paradigm of images of the English-speaking literary space and to create a dictionary of silent natural referents.

These tasks, together with the specific purpose of the study, allowed us to conduct a comprehensive analysis of natural silence in poetic discourse.

\section{Method}

Taking into account the constant interest of scientists in non-verbal communication and in discursive and pragmatic peculiarities of silence, it is crucial to study systematically the poetical images of silence and their individual psychological and socio-cultural nature.

The research material contains the texts of English-speaking authors of the 18-20th centuries, united by a standard thematic block of landscape lyrics. The validity of this material is grounded firstly because English lyrics are the foundation and basis of literary English, and secondly, we define this study as the first stage of the comprehensive research of the communicative silence implementation in the diachronic terms. The research is based on the following methods:

- classification method (to build a paradigm of landscape images of English poetry). It includes semantic classification of nature symbols, identifying components of the communicative act of silence components are used during the implementation of the communicative act of silence, revealing the motives of silence;

- deductive analysis (to study the semantic and syntactic features of the image of silence);

- $\quad$ descriptive method (for an accurate and complete description of language units that explain nature silence);

- component analysis (to study the central semantic units of silence, which are presented both in lexicographic 
sources and in English-language literary discourse for further comparison);

- communicative-pragmatic analysis (to reveal the main participants of non-verbal communication and study their behaviour, situation, and purpose);

- $\quad$ intentional analysis (for the formation and analysis of the author's intention, which is manifested in the pragmatics of the poetical silence);

- $\quad$ diachronic approach (for a comprehensive analysis of English poetical works of the 18-20th centuries).

By analysing the empirical evidence, due to poetical images' communicative approach, we distinguished all Nature Silence participants and divided them according to topographic rule into three groups: Earthy, Aerial, and Celestial. Due to the importance of such an element for the people's understanding, we considered Nature as the main element of the English landscape lyrics.

Words related to the image of Nature Silence are characterised by continuity, positional and syntactic independence, and flexibility (ability to form new words and meanings). Such characteristics are dominant for image of Nature Silence formation. This image's main verbaliser is word silence, which can be used for Homo Silence (silence of human beings) and Nature Silence.

\section{Results and Discussion}

\subsection{Lexical and Semantic Characteristics of Nature Silence}

English-language literary discourse as an empirical basis of communicatively significant silence study is valid for the experiment, as it has given the significant representation of silent situations and the corresponding narrator's interpretation (Kobyakova, 2007). In literary discourse, entirely anthropocentric, linguistic personalities are represented by the narrator and the reader. The silent effect is a kind of the core of communication, which affects writing through specific non-verbal (graphic) and verbal means. Thanks to the narrator, the reader comprehends the nature of human behaviour in the environment, as well as the mental and psychological state of the characters, including communicative silence. Communicatively significant silence in English-language literary discourse differs in its producers, which can be divided into two groups: Homo Silence (i.e, silence that is produced by human beings) and Nature Silence (silence produced by nature and its main components) (Issakova et al., 2021).

In English lyric poetry, the image of Nature and its symbols are personified and metaphorised, which allows us to speak of Nature Silence. Lexicographic analysis indicated the main lexical elements that exteriorise poetical silence and act as dominant (silence, calm, quiet, and still) and peripheral (whisper, murmur, mute, etc.) verbalisers. Three main groups present a semantic classification of Nature Silence image. Such nature symbols are very important for the English-speaking world view. Presentation of the English poetry leads to the statement that the main nature events are concentrated among real nature symbols: Earthy, Aerial, and Celestial. Earthy symbols have such components as Earth (earth, field), Water (water, ocean, stream, river, waterfall, sea, wave), and Flora (tree, flower, grass) (Figure 1).

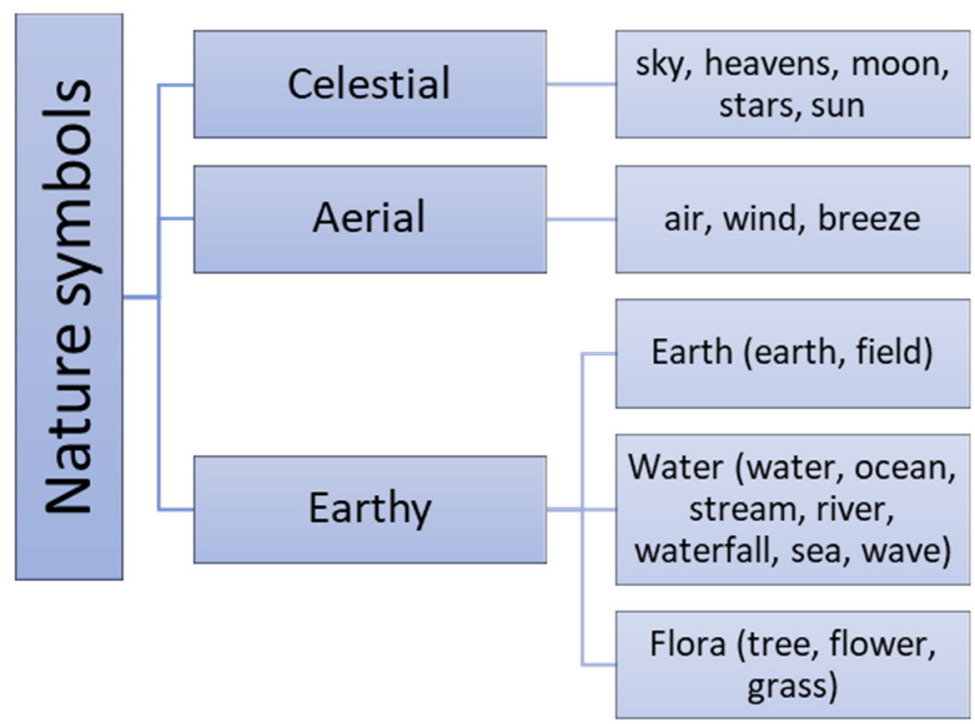

Figure 1. Semantic classification of Nature symbols

It should be noted that the image of water, in general, takes the leading position in English poetry because of the particular attitude to seas. This image evokes many associations in the British's minds; it can be associated with various 
objects and become an impetus for creating various poetical images. Maritime images in English poetry are closely connected with the folk tradition (Saray et al., 2021). It is a well-known fact that ancestors especially revered freshwater as a source of life and a boundary between the world of the living and the dead. Water has become the center of many proverbs, sayings, phraseological expressions, which figuratively depict human behaviour, e.g.: still waters have deep bottoms; we never know the value of water till the well is dry; the drop wears away the stone (Kobyakova, 2007).

On the contrary, as a component of the ocean, saltwater was perceived as the habitat of something otherworldly, incomprehensible, or hostile. The sea image in English-language poetry often contains personified elements that embody the female's insidious essence and the powerful essence of the male. Such differences in the associative understanding of this image are primarily connected with the Scandinavian mythological female deity Ran's existence, more insidious than her husband Egir, who eventually became angry with all humanity under the influence of his wife. Male sea gods embodied the ocean's power and might, while their negative qualities were considered insignificant. Perhaps that is why in English poetry and according to excerpt 1 lyrical hero often comes to the sea for advice and mental strength, and poetical silence, in turn, is the implementer of non-verbal communication between them.

(1) That strong and delicious word which, creeping to my feet, / (Or like some old crone rocking the cradle, swathed in sweet garments, bending aside,) / The sea whisper'd me (Whitman, 2012).

Images of Earth and Flora are also significant for English authors. In the time of primitive society, anthropomorphic and zoomorphic models of the universe were considered to be primary, and the world was identified either with animals or plants. To realise the image of silence, the flora plays a significant role in English-language lyrics, as the author creates unique pictures of quiet nature. In Excerpt 2 the image of Flora and Earth, in contrast to sea images, often appears as a calm observer of human actions, and the poetical silence produced by these symbols exteriorises the psycho-emotional state of the lyrical hero.

(2) Again the deathless grass, so noiseless, soft and green, / Again the blood-red roses blooming (Whitman, 2012).

In contrast to the Earthy symbols in the English-language lyrics, the Celestial ones are distinguished, as opposed to the earthy ones, according to the principle of the mythological opposition of up-down. Celestial images of the English-language landscape lyrics are represented by such elements as the sky (heavens), the moon, stars, and the sun. In English poetry, the Sky's image is characterised by such properties as absolute remoteness, inaccessibility, immutability, transcendence, and immensity. Besides, this symbol has shown the ability to create unique images of silence. The image of the Sky and the image of the Sea are sufficiently integrated into the English-language poetical space. In this case, in excerpt 3 the celestial symbols can become as separate actors, having a quiet conversation with the lyrical hero.

(3) "The stars," she whispers, "blindly run; / A web is woven across the sky; / From out waste places comes a cry, / And murmurs from the dying sun: "/ And all the phantom, / Nature, stands-- / With all the music in her tone, / A hollow echo of my own (Tennyson, 2004)

In excerpts 4 and 5, as a background image, which produces poetical silence, conveying the emotional experiences and mood of the protagonist.

(4) And, from out the silent heaven, / Silence on the town descended. Silence, silence everywhere, / On the earth and in the air (Williams \& Honig, 1962)

(5) 'T was an afternoon in Summer; / Very hot and still the air was, / Very smooth the gliding river, / Motionless the sleeping shadows: / Insects glistened in the sunshine, / Insects skated on the water, / Filled the drowsy air with buzzing, / With a far resounding war-cry (Longfellow, 2012).

The images of the moon, stars and sun often coexist with the sky's image, and the image of Sky+Stars+Moon creates a unique image of Night in English poetry. The empirical evidence analysis made it possible to comprehend the connection between the image of Night and the image of poetical silence, because, according to chronological features, Nature Silence tends to this time of the day. The percentage confirms our conclusions $-69 \%$ of the total number of silence images are characterised by a specific daily interval.

The similarity of Night image to Nature Silence is explained primarily by the sacredness and transcendence of these concepts. Night, as we know, is a time of silence and peace, a time to immerse oneself in one's thoughts and comprehend one's existence; silence is a means of creating a quiet space; and internal communication is a tool for self-knowledge. In contrast to the night symbols, in excerpt 6, the image of Sun is characterised by rarity and explains the quiet transition from night to day, while the structure of these images indicates the emotional uplift and admiration of the author.

(6) O Sun of Real Peace / O SUN of real peace! O hastening light! / O free and ecstatic! / O what I here, preparing, 
warble for! / O the sun of the world will ascend, dazzling, and take his height-- and you too, / O my Ideal, will surely ascend! (Whitman, 2012).

Nature symbols, which have the middle position to Earthy and Celestial symbols, are Aerial substantial symbols. The auxiliary elements representing aerial symbols in English poetry are air and wind (breeze). Air is one of the fundamental elements in the worldview. The breath of wind is connected with the principle of life. By creating man, God breathed life into him, and this means that the spirit of God descends on man through the breath, endowing him with unusual qualities from unearthy physical strength. In excerpt 7 , air gives the power that is not subject to any of the elements; it gives life but can easily take it away.

(7) Sweet was the air and soft; and slowly the smoke from the chimneys Rose over roofs of thatch, and pointed steadily eastward (Longfellow, 2012)

Or vice versa, in excerpt 8 , the wind may become the most potent force of nature, which can disturb even the genuine peace.

(8) And gladden these deep solitudes. / Where, twisted round the barren oak, / The summer vine in beauty clung, / And summer winds the stillness broke (Longfellow, 2012).

That is why the images of Air and Wind are so significant for English-language lyrics, because it is silence and calm that can create a moving picture of the whole lyrical work.

\subsection{Communicative and Pragmatic Characteristics of Nature Silence}

The poetical silence is characterised by the dialogical activity in fames of the communicators' interaction. As it has already been mentioned, English poetry has its paradigm of landscape images, which can form silence dialogue communication and be characterised by expressive means. Dialogue is the most productive way of interpersonal communication based on such patterns: 1) dialogue has its procedural structure, i.e., its information flow between the participants; 2) each dialogue has its environment that connects speaker, listener, relations, tone, and atmosphere in their interaction; 3) dialogue has communicative sense as a complex of the participants' interaction (Batsevych, 2010).

The dialogue structure of communication between nature and its symbols may be either inside of the group of such symbols, e.g., Earthy symbols: participants Sea+Earth; Earth+Flora, or outside it (between substantial groups of symbols), e.g., Earthy symbols (Sea)+Aerial symbols (Wind). It should be noted that such communication is based on the linear communication model by Roman Jakobson. This model is represented by the participants of communication and language means which are used in interaction. Due to this model addresser using the language means (in our case using the lexemes of silence) makes the message (forms Nature Silence) and, with the help of it, due to the context interrelates with addressee (formation of the image of poetical silence). Thus, under ideal conditions, all factors work in this model. However, practically some components of communication can become a general focus of attention. According to this, Roman Jakobson (Jakobson, 1975) distinguished the main functions of interpersonal communication.

Consequently, an emotive function is connected with addresser, i.e., speaker's personality; referential function is connected with the subject of communication, focusing on the real world; connotative function is connected with addressee using command and exclamatory form of language; poetical function has the form of a message as dominant form; metalinguistic function is based on the code of communication; phatic function is based on the context (Jakobson, 1975).

Due to poetical silence between nature symbols, we should pay attention to using such functions as connotative (exclamatory forms of sentences to create absolute Nature Silence), poetical function (using the expressive means and stylistic devices), and phatic (maintaining the absolute silence by the addressee). It is well known that man has always tried to surpass Nature's forces and, conversely, to obey it. Such relations are reflected in English poetical texts. A man asks for advice from the forces of Nature, which, in turn, responds through exteriorising poetical silence. Homo Silence can sound in unison with Nature Silence, or they can be opposed to each other. The realisation of the connotative function most often comes from the unidirectional addressee of Nature, while a Man most often performs the phatic function in maintaining absolute silence.

As the creator of all things, God plays the role of the highest power to which both man and nature are subject. Verbal communication is based on the principle of a linear model of communication, with rhizomatic connections, where God is a one-way addressee, and Nature is an addressee characterised by permanence. God alone influences Nature's forces, realising the connotative function through exclamatory sentences, which contain a call for silence. Man, in turn, without such influence on God, can address his desires to the Supreme Power or remain in the role of observer.

Communicative act is the most general concept of communicative linguistics and communication theory; it occurs in a particular place, at the intersection of the axes of space and time, which results in discourse (text) (Batsevych, 2010). 
Each communicative act has two components: situation and discourse. A situation is a fragment of an objectively existing reality, a part of which is a verbal act. A discourse is a verbalised speech-thinking activity, the components of which are linguistic (means of language code) and non-linguistic (means of other semiotic systems) components (Batsevych, 2010).

Nature Silence, as a communicative act, has the following components:

1) situation (extralinguistic aspect) - objectively available extra lingual situation of communication; conditions of communication and its participants;

2) context (semantic aspect) - implicitly or explicitly expressed meanings that exist and are part of the situation;

3) presupposition (cognitive aspect) - the area of intersection of individual cognitive spaces, in particular the understanding of the situation;

4) communication (linguistic aspect) - the product of direct creation (Batsevych, 2010).

These components are used during the implementation of the communicative act of silence in the English-language literary discourse (Figure 2). According to Figure 2, wind, aerial symbols, night objectively exist as an extralingual situation of communication. Their inner meaning is revealed by verbal markers of silence. Thus, Nature Silence contains certain motives which substantiate the essence of Nature Silence as the product of direct creation.

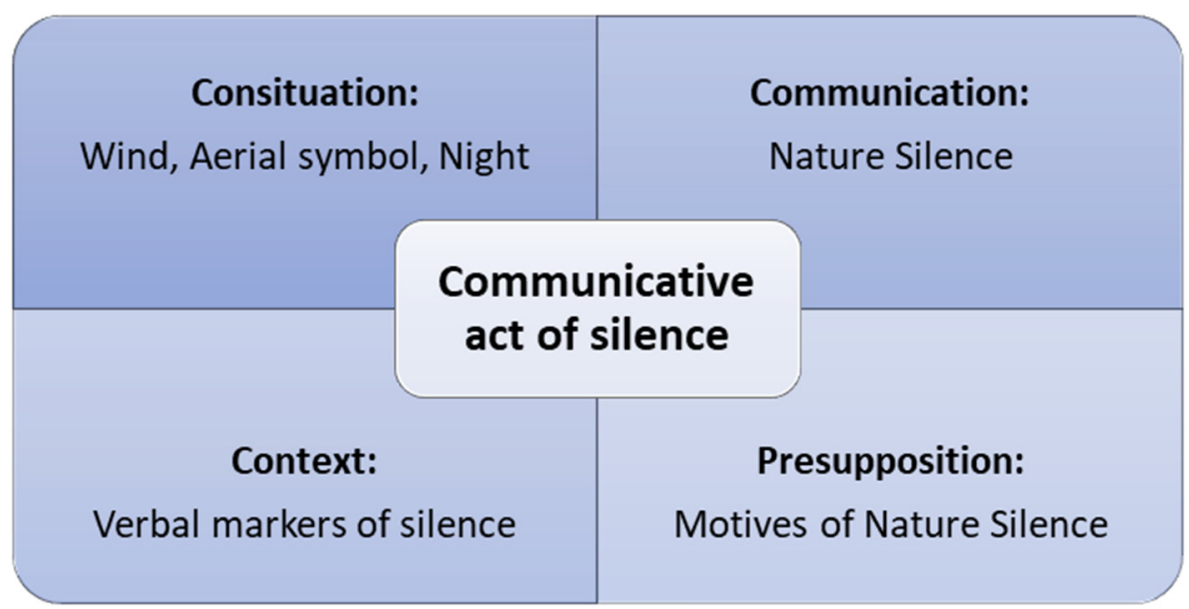

Figure 2. Communicative act of silence in English literary discourse

To create Nature Silence, authors should use both external factors (speaker, environment of communication and way of sense creating) and internal factors (nature silence, motives of nature silence, and understanding of constitution and context). It should also be noted that the communicative act occurs at several stages: 1) message implementation; 2) message sending; 3) message delivery; 4) message receiving; 5) message processing (Batsevych, 2010).

The communicative act of silence is preceded by the operation of forming a message (origin), and the source of the communicative act is the intention of the addressee, namely, the author of the literary work. The communicative intention is a meaningful or intuitive intention of the addressee, which determines the internal program of speech and its implementation (Batsevych, 2010).

Implementing the inner speech program determines the speaker's strategies and tactics to optimise the speech impact on the recipient. In this way, the meaning of the message is considered through the prism of perception. The purpose of the sentence we say is that the listener understands what we are saying and why we say it. Modern understanding of intention involves emphasising its cognitive nature - it is considered as a mental state and cognitive construct, determined by motive and purpose, as the speaker's idea, who has a volitional attitude. Intention plays an essential role in speech acts' cognitive scenario, influencing language tools for speech formation (Bezyhla, 2007).

Due to Liliia Bezyhla's (2007) research, we understand communicative intention as a kind of person's mental representation, which is the desire of the speaker to convey to the addressee a specific focus of his consciousness on the external objects and states of things, thus influence him. There are several purposes of communicative intentions, such as follows: 1) motivation as a system of motives with a dominant motive; 2) circumstances, conditions of communication, environment; 3 ) probabilistic experience related to the model of the future, i.e., the ability to predict; 4) the task (purpose for which the action is performed), i.e., the correlation of the model of the future with the immediate and future (current) action (Orazbayeva \& Nurgali, 2017). Pragmatic aspects of communication are related to subjects' interaction through language (code) (Kohut, 2021). The pragmatics of poetical images of silence manifest in two vectors: 
internally — when nature and its symbols affect each other, creating the effect of absolute silence, and externally when the finished poetical image of silence affects the recipient, creating motive and associative sketches in his mind.

When we speak about the pragmatic basis for creating a poetical image of silence, it should be noted that it is primarily related to the motive orientation of the entire poetical work and the circumstances under which it was created. The motive with the action code is embedded in the author's intention, and the author's intention with the motive and action code is embedded in the text concept (Nurgali et al., 2013). The cultural experience of the author is also an integral part of building a well-motivated image. As the main, or dominant, motive of poetical silence in English landscape poetry, we have chosen the motive of idealistic admiration for nature silence.

(9) When Spring adorns the dewy scene, / How sweet to walk the velvet green, / And hear the west wind's gentle sighs, / As o'er the scented mead it flies! (Moore, 2004)

(10) Music that floods the soul in waves of delicious sound, / Music that gushes fresh, spontaneously around, / Music in every voice and murmur of nature found, / These are the themes of song (Moore, 2004).

The excerpts 9,10 illustrate the author's love for quiet, silent nature, while in the first case, the lyrical hero enjoys the quiet, calm wind: hear the west wind's gentle sighs, while in the second example, nature silence is associated with music that fills the poet's soul: Music in every voice and murmur of nature found. Interestingly, the beauty of the silent nature in poetry is most often associated with the beauty of the native land (Khaybullina et al., 2020; Kostyuk, 2021). Nature silence and the author's admiration create a real motive of love for the native land. In excerpts 11,12 , due to the author's intentions, the native land turns into such a desirable "quiet" part of the world for a quiet and sweetheart.

(11) FIVE years have passed; five summers, with the length / Of five long winters! and again I hear / These waters, rolling from their mountain-springs / With a soft inland murmur. - Once again / Do I behold these steep and lofty cliffs, / That on a wild secluded scene impress / Thoughts of more deep seclusion; and connect / The landscape with the quiet of the sky (Eliot, 1910)

(12) But the native air is pure and sweet (Lehman, 2006).

The author continually mentions the beauty of his native land, and the poetical silence explained by verbalisers $a$ soft inland murmur, the quiet of the sky, native air is pure and sweet create the perfect image of calm Motherland. The world of silence and silent space characterises the lyrical hero's spiritual sphere, who is in a state of reflection, engaged in self-knowledge, and tries to organise his thoughts and feelings. In English lyric poetry, the motive of admiration becomes primary to creating another, which is primarily associated with the harmony of nature and man. Nature, in excerpt 13, assumes the role of a silent interlocutor, who with his tacit consent supports man. Also, Nature Silence can act as a full-fledged communicator, a participant in the communicative process.

(13) And that night, while all was still, / I heard the waters roll slowly continually up the shores, / I heard the hissing rustle of the liquid and sands, as directed to me, whispering, to congratulate me (Whitman, 2012).

(14) Where to answering, the sea, / Delaying not, hurrying not, / Whisper'd me through the night, and very plainly before daybreak (Lehman, 2006).

In excerpt 14, the nature phenomenon of Sea, which is part of the earthy symbols, assumes the only interlocutor of the lyrical hero and, with the help of the silence verbaliser to whisper, can maintain a quiet conversation with the hero. In English poetry, the harmony of man and nature can be explained not only through metaphorical conversation. In general, landscape poetry, and in particular poetical silence, play not the least role in conveying the author's or lyrical hero's feelings. In excerpt 15 , such coexistence is integrated into the poetical text in the form of a motive of the beauty of quiet nature and love.

(15) Nor the round sunshine that shine to all; / Her light shall into darkness change; / For her the green grass shall not spring, / Nor the rivers flow, nor the sweet birds sing, / Till Love have his full revenge (Tennyson, 2004).

The author's intentions are primarily aimed at showing the reader the dependence of feelings on nature's moods in a poetical word. Explicit silence, verbalised by descriptive units such as the green grass shall not spring, nor the rivers flow, nor the sweet birds sing conveys the pensive mood of nature and its phenomena and their resolute desire for silent behaviour: Till Love have his full revenge. Besides, the image of silence can be gradually transformed under the influence of the author's mood and turn into dullness and deafness of nature concerning man, which is a sign of nothingness. So, we can talk about the next motive of poetical images of silence, namely the motive of the bliss of silent nothingness. In general, images of silence and death are characterised by close connections not only in poetical texts. This correlation can be traced back to the cultural level of understanding the image of silence. Such understanding of a silence concept also exists in the treatises of mystical philosophical and religious currents. Silence has always been perceived as synonymous with humility, peace and harmony. This motive shows a high degree of integration into the 
poetical work.

(16) She looks, and her heart is in heaven: but they fade, / The mist and the river, the hill and the shade; / The stream will not flow, and the hill will not rise, / And the colours have all passed away from her eyes! (Eliot, 1910).

In excerpt 16, example is characterised by both the implicit image of silence, represented by descriptive constructions such as the stream will not flow, and the hill will not rise and the implicit image of death. Descriptive constructions play the role of a background on which tragic events unfold. Quantitative analysis of examples of such motive direction has once again confirmed a relatively high degree of integration into the English-language poetical work, the percentage of which is $32 \%$. This motive is closely related to the motive of transcendence of the quiet night.

(17) I woke, and we were sailing on / As in a gentle weather: / 'Twas night, calm night, the moon was high; / The dead men stood together (Eliot, 1910).

In excerpt 17, the author shows the magic of a quiet night, when all living things freeze, while the world of the afterlife begins to come to life in poetical spaces. Another background motive of poetical silence is shown in excerpt 18 and represented by components that create the motive of peace and absence of war.

(18) And in silence all the warriors / Broke the red stone of the quarry, / Smoothed and formed it into Peace-Pipes (Longfellow, 2012).

The background silence is characterised by people's desire to create a peaceful space, mutual understanding, and peace. Silence can characterise a whole space, subject to continuous peace without war.

(19) Winding across wide water, without sound. / The day is like wide water, without sound, / Stilled for the passing of her dreaming feet / Over the seas, to silent Palestine, / Dominion of the blood and sepulchre (Lehman, 2006).

In excerpt 19, the author, describing a charming quiet day, The day is like wide water, without sound, / Stilled for the passing of her dreaming feet, shows the desire of the lyrical hero to get to the already peaceful Palestine, Over the seas, to silent Palestine, where the war had previously taken place, Dominion of the blood and sepulcher.

The study of the empirical material revealed that, depending on the analysis perspective, silence can change the scope of its presence in work, becoming the leading background. The pragmatic specification of poetical images of silence is shown in Figure 3. Due to the motives of harmony of nature and man, the poetical silence assumes the communicator's prominent role, a participant in the action, becoming the plot's protagonist. This includes motives of harmony of man and nature and of love for the Motherland. The motive of bliss of silent nothingness, the motive of peace and absence of war, poetical silence act as a background where the poetical work's main events.

\begin{tabular}{|l|l|}
\hline Image of Silence \\
$\begin{array}{l}\text { Dominant }(45 \%) \\
\text { - Motive of harmony of man and nature }\end{array}$ \\
- Motive of love for the Motherland \\
- Motive of transcendence of quiet night
\end{tabular}

Figure 3. The main motives of the poetical image of silence

\section{Conclusions}

The basis of poetical silence as a product created by the author's intentions and worldview is a non-verbal communicative situation; the participants are nature and its symbols in the literary discourse - the vector of perception changes from purely human qualities to purely natural ones. Thus, we note that the image of silence in English-language literary discourse is considered in terms of the main, or dominant, motive, which is realised in poetry more rarely than the background. The dominant function of silence as a background is to unfold events and create the work of art's vibrant colour. In the communicative-pragmatic mode, the processes of materialisation are involved poetical silence in the communicative act. Linguo-creativity of the poetical image of silence is a combination of the principles of addressing and anthropocentrism.

The promising vector of our further investigations is connected with the idea to comprehend communicative silence in a diachronic dimension based on literary discourses of the English and Ukrainian languages.

\section{References}

Aimukhambet, Z. A., Abdilmanatkyzy, A., Baitanasova, K., Seiputanova, A., \& Kurmambayeva, K. (2017). The poetic 
interpretation of binary opposition in the structure of Myth. Rupkatha Journal on Interdisciplinary Studies in Humanities, 9(1), 11-20.

Akmajian, A. (2001). Linguistics: an introduction to language and communication. London: The MIT Press.

Batsevych, F. (2010). Fundamentals of communicative deviatology. Lviv: Ivan Franko Lviv National University.

Bezyhla, L. (2007). Verbalising implicit senses in German dialogical discourse. Kharkiv: Vasyl Karazin Kharkiv National University.

Carnap, R. (1939). Foundations of logic and mathematics. Chicago: University of Chicago Press

Eliot, C. W. (1910). The Harvard classics. English poetry. New York: P. F. Collier \& Son Corporation.

Issakova, S. S., Kuzdybaeva, A. A., Sadirova, K. K., Kussaiynova, Z. A., Adilbayeva, U. B., \& Utelbayeva, G. U. (2021). The cognitive aspect of modality in English texts. Astra Salvensis, 2021, 137-148.

Khaybullina, A. A., Nagumanova, E. F., \& Nurgali, K. R. (2020). Genre strategy of modern Russian-language poetry in Kazakhstan. International Journal of Criminology and Sociology, 9, 2609-2615.

Kobyakova, I. (2007). Creative construction of the secondary compositions in English literary discourse. Vinnytsia: Nova Knyha.

Kohut, O. O. (2020). The concept of integrative development of the personality's tolerance to stress in systemic discourse. Scientific Bulletin of Mukachevo State University. Series "Pedagogy and Psychology", 6(2), 113-123.

Kostyuk, O. (2021). The most important thing in life is beauty. Foreign Affairs, 31(5), 97-102.

Kulakhmetova, M., Shakharman, A., Mustafayeva, A., \& Altybassarova, M. (2017). Religious discourse in Kazakh: Description and structure. Ponte, 73(1), 157-165.

Lehman, D. (2006). The Oxford book of American poetry. Oxford: Oxford University Press.

Longfellow, H. (2012). Poems. Retrieved from https://www.poemhunter.com/i/ebooks/pdf/henry_wadsworth_longfellow_2012_6.pdf

Moore, T. (2004). The complete poems of Sir Thomas Moore collected by himself with explanatory notes. Retrieved from https://biblioteca.org.ar/

Nurgali, K. R., Baytanasova, K. M., \& Kishkenbaeva, J. K. (2013). Author's role in the literary field by the example of Kazakh literature. World Applied Sciences Journal, 25(9), 1290-1294.

Orazbayeva, N., \& Nurgali, K. (2017). Russian writers with bimental thinking and the formation of readers' multicultural competence. Pertanika Journal of Social Sciences and Humanities, 25(2), 823-836.

Romaniuk, O. (2018). Feminine contact-establishing communicative tactic within the framework of romantic discourse. Analele Universitatii din Craiova - Seria Stiinte Filologice, Lingvistica, 40(1-2), 170-181.

Romaniuk, O. (2019). Effective self-disclosure within the masculine romantic discourse: variable communicative moves. Analele Universitatii din Craiova - Seria Stiinte Filologice, Lingvistica, 41(1-2), 139-156.

Saray, S., Satır, T., \& Dogan-Saglamtimur, N. (2021). Proficiency of Maritime English course: An investigation in Istanbul, Turkey. Heritage and Sustainable Development, 3(1), 6-15.

Skliarenko, O., Akimova, A., \& Svyrydenko, O. (2019). Psycholinguistic peculiarities of contextual realisation of concept «macht» in linguistic and cultural space of German's. Psycholinguistics, 26(2), 321-340.

Tennyson, A. (2004). Poems. Retrieved from https://dokumen.tips/documents/alfred-lord-tennyson-poems.html

Tsvetkova, M., Evreeva, O., Saenko, N., \& Maltseva, S. (2021). Religious fabula as a means of increasing the mass readership. Revista Transilvania, 2021(5), 38-45.

Whitman, W. (2012). Poems. Retrieved from https://www.poemhunter.com/i/ebooks/pdf/walt_whitman_2012_5.pdf

Williams, O., \& Honig, E. (1962). The Mentor book of Major American Poets. New York: Mentor book.

\section{Copyrights}

Copyright for this article is retained by the author(s), with first publication rights granted to the journal.

This is an open-access article distributed under the terms and conditions of the Creative Commons Attribution license which permits unrestricted use, distribution, and reproduction in any medium, provided the original work is properly cited. 